\title{
Sealing ability of MTA, Super EBA, Vitremer and amalgam as root-end filling materials
}

\section{Capacidade de selamento de MTA, Super EBA, Vitremer e amálgama como materiais retrobturadores}

\author{
Cecília Luiz Pereira* \\ Maximiliano Sérgio Cenci** \\ Flávio Fernando Demarco***
}

\begin{abstract}
This study evaluated the root-end sealing ability of mineral trioxide aggregate (MTA Angelus), reinforced zinc oxide-eugenol cement (Super EBA), resin-modified glass ionomer (Vitremer) and zinc-free amalgam (GS-80) (control). The root canals of eighty human lower molars were accessed, cleansed, shaped and obturated. Apexes were resected and cavities were prepared. Teeth were divided into 4 groups of 40 cavities, root-end filled with the materials, and immersed in methylene blue for $72 \mathrm{~h}$ at $37^{\circ} \mathrm{C}$. Roots were then sectioned transversally at each millimeter and evaluated under magnification, observing the dye penetration in each section. Data were evaluated using Kruskal-Wallis test at a 5\% level of significance, showing the differences among all materials $(\mathrm{p}<0.001)$. The crescent order of microleakage was MTA $<$ Vitremer $<$ Super EBA $<$ amalgam. Higher leakage levels were observed in the first millimeter sections of amalgam, Vitremer and MTA, when compared with the third millimeter section $(\mathrm{p}<0.05)$.
\end{abstract}

DESCRIPTORS: Dental leakage; Glass ionomer cements; Zinc oxide-eugenol cement.

\begin{abstract}
RESUMO: Este estudo avaliou a capacidade de selamento do agregado trióxido mineral (MTA Angelus), de um cimento de óxido de zinco e eugenol reforçado (Super EBA), de um cimento de ionômero de vidro reforçado por resina (Vitremer) e de um amálgama sem zinco (GS-80) (controle). Os canais radiculares de oitenta molares inferiores humanos foram acessados, limpos, modelados e obturados. Os ápices foram seccionados, e as cavidades, preparadas. Os dentes foram divididos em 4 grupos de 40 cavidades, retrobturados com os materiais e imersos em azul de metileno por $72 \mathrm{~h} \mathrm{a} 37^{\circ} \mathrm{C}$. As raízes foram então seccionadas transversalmente a cada milímetro e avaliadas sob aumento, observando-se a penetração de corante a cada corte. Os dados foram avaliados usando-se o teste de Kruskal-Wallis $(5 \%)$, que mostrou diferenças entre todos os materiais $(\mathrm{p}<0,001)$. A ordem crescente de infiltração marginal foi MTA < Vitremer < Super EBA < amálgama. Niveis mais altos de infiltração foram observados nos cortes de primeiro milímetro de amálgama, Vitremer e MTA, quando comparados com o terceiro milímetro $(p<0,05)$. DESCRITORES: Infiltração dentária; Cimentos de ionômeros de vidro; Cimento de óxido de zinco e eugenol.
\end{abstract}

\section{INTRODUCTION}

Pulpal and periradicular pathoses develop more frequently in consequence of the bacterial contamination of these tissues. The removal of irritant factors and the adequate sealing of the canal system should be achieved through its complete cleaning, shaping and obturation, resulting in the resolution of periradicular lesions. When healing is not achieved after non-surgical endodontic therapy, and when retreatment is not possible or has failed, the surgical approach is indicated ${ }^{8}$. The procedure routinely consists of the exposure and resection of the involved apex, the preparation of a class I cavity and the insertion of a root-end filling material ${ }^{17,20}$.
The root-end filling material should improve the sealing of the existing canal filling or provide an apical sealing to an otherwise unobturated root canal, preventing the movement of bacteria and bacterial products from the root canal system to periapical tissues ${ }^{6,17}$. These substances should also be biocompatible, non-toxic, non-carcinogenic, easy to use, and should not be sensitive to moisture ${ }^{7,9}$.

With the purpose of obtaining root-end sealing in endodontic surgery, many different materials have been suggested. The most commonly used ones are amalgam, glass ionomer cement, zinc oxide, eugenol cement, gutta-percha and com-

\footnotetext{
*DDS; ${ }^{* *} \mathrm{MSc} ;{ }^{* * *} \mathrm{PhD}-$ Department of Restorative Dentistry, School of Dentistry, Federal University of Pelotas.
} 
Pereira CL, Cenci MS, Demarco FF. Sealing ability of MTA, Super EBA, Vitremer and amalgam as root-end filling materials. Braz Oral Res 2004;18(4):317-21.

posite resins ${ }^{9}$. More recent studies have shown mineral trioxide aggregate (MTA) as a promising material for root-end filling ${ }^{12-14}$. Root-end filling materials have been tested for leakage assessment, marginal adaptation, cytotoxicity and usage tests ${ }^{4,6,12,14,18,20}$.

Clinical evaluations represent the basis for the selection of materials, but they are expensive, time-consuming and sometimes not ethically feasible. Therefore, in vitro investigations such as microleakage tests have been carried out to evaluate the performance of new materials and techniques. In addition, in vitro tests are adequate for screening new methodological possibilities.

The purpose of this study was to evaluate the sealing ability of mineral trioxide aggregate (MTA Angelus), reinforced zinc oxide-eugenol cement (Super EBA), resin-modified glass ionomer (Vitremer) and zinc-free amalgam (GS-80) (control) as root-end filling materials. The null hypothesis tested was that there would be no difference between the sealing ability of the materials.

\section{MATERIAL AND METHODS}

Eighty extracted human lower molars were selected and previously rehydrated in saline solution for 30 days $^{10}$. The access preparations were performed, and root canals were cleansed and shaped using Gates-Glidden drills and K-File, K-Flexofile and Hedströem files (Maillefer Instruments, Ballaigues, Switzerland) combined with 1\% sodium hypochlorite (Inodon, Porto Alegre, Brazil) and EDTA irrigation solution (Inodon, Porto Alegre, Brazil), following a serial step-back technique. The instrumented canals were then obturated with laterally condensed gutta-percha cones (Dentsply, Petrópolis, Brazil) and zinc oxide-eugenol sealer (Endofill - Dentsply, Petrópolis, Brazil).

The apical $3 \mathrm{~mm}$ of each root were resected with approximately a $45^{\circ}$ bevel using a \#3215 diamond point (SS White, Rio de Janeiro, Brazil) in a high-speed handpiece (Dabi Atlante, Ribeirão Preto, Brazil) with copious water spray. Class I root-end preparations were then performed, using a \#2 bur (SS White, Rio de Janeiro, Brazil) at low speed. The cavities had a circular shape in single-canal roots, and involved the canals and the isthmus when two canals were present. Each cavity was $3 \mathrm{~mm}$ deep, and the burs were replaced after 5 preparations.

The specimens were randomly divided into four groups of 40 cavities. Products and manu-
TABLE 1 - Products and manufacturers.

\begin{tabular}{l|l}
\hline \hline \multicolumn{1}{c|}{ Product } & \multicolumn{1}{c}{ Manufacturer } \\
\hline GS-80 amalgam & $\begin{array}{l}\text { Southern Dental Industries, } \\
\text { Bayswater, Vic., Australia }\end{array}$ \\
\hline $\begin{array}{l}\text { Universal cavity } \\
\text { varnish }\end{array}$ & $\begin{array}{l}\text { SS White, Rio de Janeiro, RJ, } \\
\text { Brazil }\end{array}$ \\
\hline Super EBA & $\begin{array}{l}\text { Harry Bosworth Co., Skokie, IL, } \\
\text { USA }\end{array}$ \\
\hline Vitremer & 3M ESPE, St.Paul, MN, USA \\
\hline MTA & Angelus, Londrina, PR, Brazil \\
\hline \hline
\end{tabular}

TABLE 2 - Scores of microleakage: percentage of tooth/ material interface with dye penetration in each section.

\begin{tabular}{c|c}
\hline \hline Score & Observed microleakage \\
\hline 0 & No microleakage \\
\hline 1 & Up to $25 \%$ \\
\hline 2 & $25-50 \%$ \\
\hline 3 & $50-75 \%$ \\
\hline 4 & $75-100 \%$ \\
\hline \hline
\end{tabular}

facturers are shown in Table 1 . In all groups, materials were used according to the manufacturer's instructions. In the amalgam group, a cavity varnish was applied with a microbrush (KG Sorensen, Barueri, Brazil), and amalgam fillings were condensed with a small plugger and carved. Super EBA was prepared to have a thin consistency (2 scoops of regular set powder: 3 drops of liquid), and was placed with a Mark IIIp syringe (Centrix Inc., Shelton, CT, USA), using a needlepoint deliverer. Vitremer was also applied with a Mark IIIp syringe, and the photopolymerization was performed using a XL 3000 light-curing unit (3M ESPE, Saint Paul, USA). The mineral trioxide aggregate was mixed (1 scoop of powder: 1 drop of distilled water), applied with a small amalgam carrier, and adapted with a spatula. In all groups, the excess material was removed with an instrument to promote a regular surface. Following restoration, teeth were isolated with cyanoacrylate cement (Super Bonder, Loctite, São Paulo, Brazil) and nail varnish (Impala, Guarulhos, Brazil), except for the resected apical surface. Specimens were then washed with saline solution (Aster, Sorocaba, SP, Brazil), fixed in a thick wax support (Clássico, São Paulo, Brazil), and immersed vertically in 1\% methylene blue (Khautz Farmácia, Pelotas, Brazil) solution, pH 7.0, for 72 
Pereira CL, Cenci MS, Demarco FF. Sealing ability of MTA, Super EBA, Vitremer and amalgam as root-end filling materials. Braz Oral Res 2004;18(4):317-21.

TABLE 3 - Frequency of microleakage scores at each millimeter.

\begin{tabular}{|c|c|c|c|c|c|c|c|c|c|c|c|c|c|c|c|c|c|c|c|c|}
\hline \multirow{3}{*}{ Depth } & \multicolumn{20}{|c|}{ Frequency of microleakage scores } \\
\hline & \multicolumn{5}{|c|}{ MTA } & \multicolumn{5}{|c|}{ Vitremer } & \multicolumn{5}{|c|}{ Super EBA } & \multicolumn{5}{|c|}{ Amalgam } \\
\hline & 0 & 1 & 2 & 3 & 4 & 0 & 1 & 2 & 3 & 4 & 0 & 1 & 2 & 3 & 4 & 0 & 1 & 2 & 3 & 4 \\
\hline $1 \mathrm{~mm}$ & 36 & 4 & 0 & 0 & 0 & 26 & 10 & 4 & 0 & 0 & 6 & 10 & 3 & 3 & 18 & 0 & 0 & 1 & 4 & 35 \\
\hline $2 \mathrm{~mm}$ & 40 & 0 & 0 & 0 & 0 & 30 & 8 & 2 & 0 & 0 & 10 & 8 & 4 & 2 & 16 & 0 & 1 & 2 & 4 & 33 \\
\hline $3 \mathrm{~mm}$ & 40 & 0 & 0 & 0 & 0 & 35 & 5 & 0 & 0 & 0 & 13 & 6 & 2 & 4 & 15 & 1 & 2 & 2 & 9 & 26 \\
\hline
\end{tabular}

hours, at $37^{\circ} \mathrm{C}$. Only the apical halves of the roots were in contact with the dye.

Teeth were then removed from the dye, washed for 12 hours in tap water and the cyanoacrylate/ nail varnish cover was removed. The roots were transversally sectioned at each millimeter of the root-end filling using a diamond saw (KG Sorensen, Barueri, Brazil) at low speed, without water cooling to prevent dye removal, resulting in 3 sections per root. The sections were considered as first, second and third millimeter in an apex-crown orientation. Two calibrated examiners evaluated the sections with a stereomicroscope (40 X magnification) (Tecnical, Biosystems, Curitiba, Brazil), recording the dye penetration in each section using a standard score (Table 2). Data were submitted to statistical analysis using the non-parametric Kruskal-Wallis test.

\section{RESULTS}

The statistical analysis showed significant differences among all tested materials at a 0.001 level of significance. Amalgam presented higher leakage levels than the other groups, and the best sealing was obtained with MTA. The ascending order of marginal leakage was MTA $<$ Vitremer $<$ Super EBA < amalgam (Table 3).

When the scores of different depths were compared, the first millimeter sections showed statistically significant higher leakage rates than the second and third millimeter sections $(\mathrm{p}<0.05)$ in the MTA group. Vitremer and amalgam presented statistically higher leakage rates in the first millimeter section when compared with the third millimeter section $(\mathrm{p}<0.05)$. The Super EBA group showed no significant differences among the leakage scores of the three sections.

\section{DISCUSSION AND CONCLUSION}

One of the most frequently used methods to assess the sealing ability of root-end filling materi- als is dye leakage, in spite of its limitations ${ }^{20}$. Since dye particles are smaller than bacteria, microleakage could overestimate bacterial penetration ${ }^{17}$. On the other hand, it could provide an estimation of the sealing ability under extreme circumstances.

Dye penetration studies have also been criticized for the limitations of the microleakage evaluation in one plane, as usually performed in these investigations ${ }^{5}$. In the present study, the degrees of dye leakage were measured using serial transverse sections of each specimen, which allowed a more reliable assessment of the sealing ability of the materials. Evaluation of dye penetration along the materials is important to estimate the material's clinical behavior, since the presence of leakage in the first or second millimeter sections could be a facilitator of dye penetration in the third millimeter section over time.

Apicoectomies were performed in a 45-degree linguo-buccal bevel, as often used in vivo. This procedure could decrease the crown-root ratio and also increase the apical leakage, due to the permeability of the dentinal tubules that are more exposed by the bevel angle ${ }^{11,20}$, but a beveled resected root is necessary for good visibility when conventional burs in a handpiece are used for the class I cavity preparation. Ultrasonic instruments appear to be an option for root-end preparations using perpendicular apex resections. However, such instruments are not always available, and the surgical technique with burs and a handpiece is still widely used by many clinicians, especially in economically unprivileged contexts. O'Connor et al. ${ }^{11}$ (1995) showed no significant differences between the preparation with ultrasonic tips or handpiece in the sealing of root-end fillings.

GS-80 is a zinc-free spherical amalgam, composed of $\mathrm{Ag}(40 \%), \mathrm{Sn}(31.3 \%), \mathrm{Cu}(28.7 \%)$ and $\mathrm{Hg}$ (47.9\%). The amalgam group presented the worst results in spite of the use of cavity varnish, which could enhance the short-term sealing of amalgam fillings. The long-term sealing of amalgam tends to 
Pereira CL, Cenci MS, Demarco FF. Sealing ability of MTA, Super EBA, Vitremer and amalgam as root-end filling materials. Braz Oral Res 2004;18(4):317-21.

improve with time, as the gaps in the tooth/filling interface become filled with corrosion products ${ }^{4}$. There are few reports comparing amalgam with Super EBA, Vitremer and MTA. The results obtained in this study agree with those of O'Connor et al. ${ }^{11}$ (1995), in a study comparing amalgam with Super EBA. Fogel, Peikoff ${ }^{6}$ (2001) also showed more microleakage with amalgam than with Super EBA, dentin-bonded resin or MTA, using a fluid filtration system.

Reinforced zinc oxide-eugenol cement (Super EBA) has become an alternative to amalgam, and it is generally accepted as an effective root-end filling material. As suggested by Yaccino et al. ${ }^{22}$ (1999), a Centrix syringe was used to fill the root-end cavities with Super EBA, since the consistency and the setting time of the material may cause difficulty in handling it clinically. Super EBA showed less leakage than amalgam, but more leakage than the other two materials. Wu et al. ${ }^{21}$ (1998) obtained similar results in a long-term study of the sealing ability of Super EBA, amalgam, glass ionomer cements and MTA using a fluid transport model.

The resin-modified glass ionomer cement (Vitremer) showed less dye penetration than amalgam and reinforced zinc oxide-eugenol cement. Glass ionomer cements have been reported to have several advantageous properties for their use as restorative materials, such as adhesiveness to tooth structure and antimicrobial activity ${ }^{17}$. Chong et al. ${ }^{2}$ (1997), comparing the short-term tissue response to different root-end filling materials, obtained better results with a resin-modified glass ionomer cement (Vitrebond) when compared to amalgam. The use of a light-cured resin-modified glass ionomer also allows better working time control, which is an important factor during a surgical procedure. However, the results of this study might have been different if the material had been placed in the

\section{REFERENCES}

1. Chong BS, Pitt Ford TR, Hudson MB. A prospective clinical study of mineral trioxide aggregate and IRM when used as root-end filling materials in endodontic surgery. Int Endod J 2003;36:520-6.

2. Chong BS, Pitt Ford TR, Kariyawasam SP. Short-term tissue response to potential root-end filling materials in infected root canals. Int Endod J 1997;30:240-9.

3. Chuang SF, Jin YT, Tsai PF, Wong TY. Effect of various surface protections on the margin microleakage of resin-modified glass ionomer cements. J Prosthet Dent 2001;86:30914. presence of blood or water, since resin-modified glass ionomers might be sensitive to moisture ${ }^{3}$.

The mineral trioxide aggregate (MTA) showed the best sealing ability. Fischer et al. ${ }^{5}$ (1998) obtained similar results, comparing MTA with amalgam, IRM and Super EBA in a bacterial leakage test. Shipper et al. ${ }^{16}$ (2004), in an evaluation of marginal adaptation using scanning electron microscopy, found superior results with MTA when compared with amalgam. Torabinejad, Chivian ${ }^{19}$ (1999) found that the use of MTA as a root-end filling material, when compared with amalgam in studies with dogs and monkeys, was associated with less inflammation, formation of cementum over MTA and regeneration of the periradicular tissues to almost normal preexperimental status. Schwartz et al. ${ }^{15}$ (1999) pointed out the successful results the material achieved in a range of in vitro and in vivo tests, which has supported its use in various clinical applications since its approval by the U.S. Food and Drug Administration in 1998. A prospective clinical study resulting from the use of MTA was recently released and showed satisfactory results in a 24-month postoperative evaluation ${ }^{1}$.

The tested null hypothesis was rejected, since materials presented statistically different results concerning their sealing ability. The knowledge acquired from previous investigations and supported by our findings suggests that MTA is a promising alternative in several clinical situations. However, further studies comparing materials and techniques are necessary to establish adequate and definitive protocols for endodontic surgery.

\section{ACKNOWLEDGMENTS}

This study was financially supported by CNPq (Brazilian Council for Scientific and Technological Development).

4. Dorn SO, Gartner AH. Retrograde filling materials: a retrospective success-failure study of amalgam, EBA, and IRM. J Endod 1990;16:391-3.

5. Fischer EJ, Arens DE, Miller CH. Bacterial leakage of mineral trioxide aggregate as compared with zinc-free amalgam, intermediate restorative material and Super-EBA as a root-end filling material. J Endod 1998;24:176-9.

6. Fogel HM, Peikoff MD. Microleakage of root-end filling materials. J Endod 2001;27:456-8.

7. Gartner AH, Dorn SO. Advances in endodontic surgery. Dent Clin North Am 1992;36:357-78. 
Pereira CL, Cenci MS, Demarco FF. Sealing ability of MTA, Super EBA, Vitremer and amalgam as root-end filling materials. Braz Oral Res 2004;18(4):317-21.

8. Greer BD, West LA, Liewehr FR, Pashley DH. Sealing ability of Dyract, Geristore, IRM and Super-EBA as root-end filling materials. J Endod 2001;7:441-3.

9. Jou Y, Pertl C. Is there a best retrograde filling material? Dent Clin North Am 1997;41:555-61.

10. Muench A, da Silva EM, Ballester RY. Influence of different dentinal substrates on the tensile bond strength of three adhesive systems. J Adhes Dent 2000;2:209-12.

11. O'Connor RP, Hutter JW, Roahen JO. Leakage of amalgam and Super-EBA root-end fillings using two preparation techniques and surgical microscopy. J Endod 1995;21:748.

12. Peters CI, Peters OA. Occlusal loading of EBA and MTA root-end fillings in a computer-controlled masticator: a scanning electron microscopic study. Int Endod J 2002; 35:22-9.

13. Pistorius A, Willershausen B, Briseno Marroquin B. Effect of apical root-end filling materials on gingival fibroblasts. Int Endod J 2003;36:610-5.

14. Regan JD, Gutmann JL, Witherspoon DE. Comparison of Diaket and MTA when used as root-end filling materials to support regeneration of the periradicular tissues. Int Endod J 2002;35:840-7.
15. Schwartz RS, Mauger M, Clement DJ, Walker WA. Mineral trioxide aggregate: a new material for endodontics. J Am Dent Assoc 1999;130:967-75.

16. Shipper G, Grossman ES, Botha AJ, Cleaton-Jones $\mathrm{PE}$. Marginal adaptation of mineral trioxide aggregate (MTA) compared with amalgam as a root-end filling material: a low-vacuum (LV) versus high-vacuum (HV) SEM study. Int Endod J 2004;37:325-36.

17. Siqueira Júnior JF, Rôças IN, Abad E, Castro AJR, Gahyva SM, Favieri A. Ability of three root-end filling materials to prevent bacterial leakage. J Endod 2001;27:673-5.

18. Subay RK, Subay A. In vitro sealing ability of dentin bonding agents and cavity varnish with amalgam as retrofills. J Endod 1999;25:157-60.

19. Torabinejad M, Chivian N. Clinical applications of mineral trioxide aggregate. J Endod 1999;25:197-205.

20. Torabinejad M, Pitt Ford TR. Root end filling materials: a review. Endod Dent Traumatol 1996;12:161-78.

21. Wu MK, Kontakiotis EG, Wesselink PR. Long-term seal provided by some root-end filling materials. J Endod 1998;24:557-60.

22. Yaccino JM, Walker WA, Carnes DL, Schindler WG. Longitudinal evaluation of Super-EBA as a root-end sealing material. J Endod 1999;25:552-4.
Received for publication on May 26, 2004

Sent for alterations on Jul 20, 2004 Accepted for publication on Aug 31, 2004 